\title{
Research on the Policy Drivers of the Financial Leasing Industry in the Free Trade Area
}

\author{
Wei Li \\ Harbin, Heilongjiang Province, China \\ Department of Finance and Public Management, School of \\ Economics, Tianjin University of Finance and Economics \\ Email: liwei1101@126.com
}

\author{
Congcong Bian* \\ Graduate students in Finance, Students of the Department of \\ Finance and public administration of Tianjin University of \\ Finance and Economics. \\ Email: 13820906512@163.com
}

\begin{abstract}
Financial leasing not only satisfies the financing needs of some small and medium enterprises, but also provides a good investment channel for many potential investors. With the continuous development of this industry in recent years, the government's supporting public service policy and the management mode of industry entities are also being adjusted simultaneously. This paper introduces the supporting public service policies of the financial leasing industry in the free trade area, such as tax, credit, industrial import and export policy, and the management of legal person in the industry. This paper focuses on the specific measures, such as increasing government preference, expanding industry service areas and strengthening the risk management in free trade area.
\end{abstract}

Keywords-Financial leasing; Free Trade Area; Policy drivers; Industry entry and exit thresholds

\section{OVERVIEW OF FINANCIAL LEASING}

\section{A. Theoretical basis for financial leasing}

Financial leasing is a kind of transaction that achieves the purpose of "financing" by means of "melt" [1]. Specifically, the Financial leasing is when enterprises or institutions need to buy equipment, not to use its own funds or loans to financial institutions to buy, but the rental party is leasing company according to the requirements of the enterprise, will buy equipment rental for the use of the lessee to financial institutions financing through its own funds or the lessor, the lessee in accordance with the provisions of the financial leasing contract, regular pay rent to the lessor, choose a transaction purchase, lease, renewal after the expiry of the lease. The financial leasing process involves three parties, the supplier, the lessor and the lessee, which need to sign two contracts, one is the seller and the lessor signed a contract of sale, the other is the lessor and the lessee signed a lease contract, the lessee and the supplier have no direct contractual relationship [2].

TABLE I.

TYPES OF FINANCIAL LEASING COMPANIES, REGULATORS AND SCOPE OF BUSINESS

\begin{tabular}{|c|c|c|}
\hline type & Regulatory bodies & service range \\
\hline $\begin{array}{c}\text { Foreign financial leasing } \\
\text { companies }\end{array}$ & Ministry of Commerce & $\begin{array}{c}\text { Intangible assets such as movable property, } \\
\text { technology, software and leasing of aircraft, ships, } \\
\text { etc.. }\end{array}$ \\
\hline $\begin{array}{c}\text { Financial leasing } \\
\text { companies }\end{array}$ & CBRC & Leasing of fixed assets \\
\hline $\begin{array}{c}\text { Domestic pilot leasing } \\
\text { agencies }\end{array}$ & Ministry of Commerce & No clear operational specifications \\
\hline
\end{tabular}


B. The current situation of financial leasing industry

TABLE II. NUMBER AND BUSINESS VOLUME OF FINANCIAL LEASING ENTERPRISES IN CHINA

\begin{tabular}{ccc}
\hline age & $\begin{array}{c}\text { Number of financial leasing enterprises in } \\
\text { our country }\end{array}$ & $\begin{array}{c}\text { The total amount of financial leasing } \\
\text { business in our country(Billion) }\end{array}$ \\
\hline 2011 & 369 & 9300 \\
2012 & 643 & 15500 \\
2013 & 1106 & 21000 \\
2014 & 2202 & 32000 \\
2015 & 4508 & 44400 \\
2016 & 7136 & 53300 \\
\hline
\end{tabular}

a. Data source: China Leasing Union, "The Development of the Number of Chinese Financial Leasing Enterprises 2006-2016", "The Development of the National Finance Lease Business in 2016"

From the table we can see that our country to the end of 2016, with 7136 financial leasing companies, only 369 in 2011 , in 2016 the number of leasing companies is 18 times as much as in 2011,The business volume growth of nearly 5 times. In addition to China by the end of 2016, with 7136 financial leasing companies, including financial leasing 59 home, domestic leasing 205, foreign leasing 6872. At the same time, most of these financial leasing companies are from the free trade area. The so-called free trade area, which can make free trade policy and preferential open policy in the region, expand trade volume and increase foreign exchange income, thus promote the economic development of a region, so the financial leasing industry in the free trade area has developed rapidly [3]. Thanks to the preferential and convenient policies of the free trade area, the financial leasing industry in the free trade area has developed rapidly. But the financial leasing industry also encountered many problems in the fast development of the free trade area.

\section{CONSTRAints In THE DEVELOPMENT OF THE \\ FinANCIAL LEASING INDUSTRY IN FREE TRADE AREA}

\section{A. Type of business is relatively single}

At present, our country mainly for the simple direct financial leasing business and similar to the bank mortgage loan after-lease business. Although the management model has completed SPV lease, offshore lease, asset charter lease, but the scope of the business is not wide enough. The single type of business will hinder the international competitiveness of the financial leasing company in our country. Because of the late start of financial leasing industry in our country, people's understanding and understanding of it is not enough, so there are still many constraints in expanding the scope of leasing business.

\section{B. The normative institutional factors such as laws and regulations are not perfect}

On the one hand, there are three types of financial leasing enterprises, which are regulated by the CBRC and the Ministry of Commerce. Because the subject of supervision is different, the standards of supervision will be different. On the other hand, the contract law is a problem. Currently, the law on financial leasing business is the chapter "financial leasing contract "and Interpretation of the applicable law in cases of disputes over financial leasing contracts. Generally speaking, the law is weak and there is a lack of regional and systematic standards.

\section{The government's policy drive is not enough}

\section{1) Fiscal aspects}

As a new industry, financial leasing industry really needs a number of supporting policies that reflect the characteristics of the leasing business and the stages of development. The United States has established a system of preferential tax policies aimed at financial leasing, and there is no similar industry tax preference system in our country [4].

After the reform of the tax system, the financial leasing company needs to pay VAT in the leasing process. The financial leasing business often involves cross period, the purchase of equipment value-added tax burden of financial leasing companies, as the input tax deductible in the amount, but the rental business practice, the supplier often put an invoice to the lessor, but the lessor is staging the rent bill to the lessee, which will lead to rent one is greater than the input tax in the lease period the output tax, but in the early stage of the lease income often is greater than the output, therefore, does not need to pre tax, post centralized pay, the value-added tax burden does not have to bear. This situation may lead to the crisis of the cash flow of the financial leasing enterprises in the later period, and there are certain operational risks. In terms of income tax, the fixed assets leased by a financial leasing company shall not be depreciated and shall be deducted before tax. In this way, the financial leasing company will have to all the rental income into taxable 
income, to a certain extent, affecting the leasing company's business development initiative.

\section{2) Industry access thresholds}

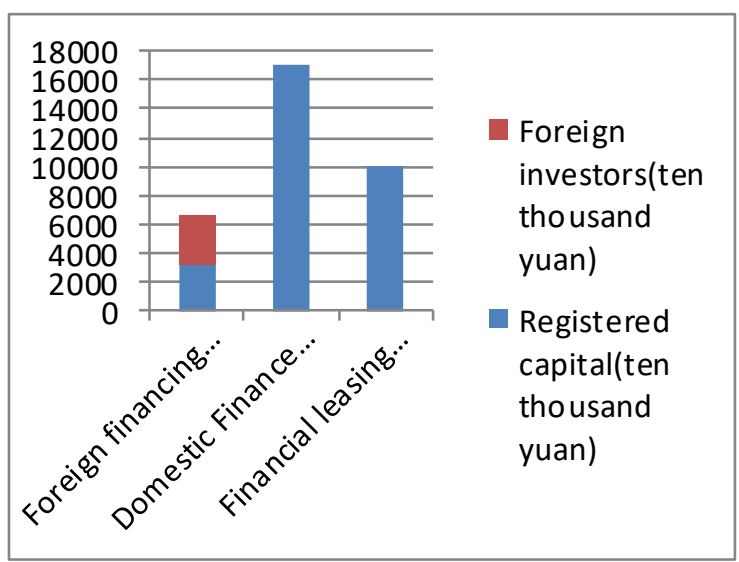

Fig. 1. Registered capital requirements for three types of finance leasing companies

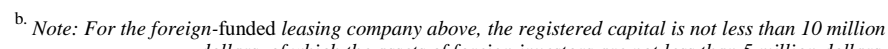
dollars, of which the assets of foreign investors are not less than 5 million dollars.

The entrance threshold is too high to make the enterprise without the rich capital strength can not enter the domestic capital pilot financial leasing enterprise. In contrast, the low market entry threshold for foreign-funded leasing companies leads to uneven access to foreign leasing companies in the region, while also crowding out some domestic leasing institutions. High registered capital and restrictions on investors are not conducive to the balanced development of the whole financial leasing industry.

\section{3) Credit policy}

According to the financing channels of leasing institutions, domestic financial leasing companies and financial leasing companies rely mainly on the direct injection of financial institutions such as commercial banks [5]. Commercial banks, based on the principles of profit maximization and high returns due to high risk to the leasing enterprise financing costs, the transfer to the leasing enterprise will bear a higher rent burden, if the leasing cost is higher than the leasing enterprise directly from the bank to apply for the cost of the funds, the leasing enterprise is clearly more willing to apply for loans directly to the bank, compared to the leasing business to buy fixed assets bank loans more extensive use. According to the operation characteristics of the financial leasing company, its business also has the extremely high capital risk, when the assets involved, such as aircraft, ship, individual equipment acquisition funds are larger, the total expenditure may be several times higher than the financial leasing company's own funds, even dozens of times, once the finance leasing company broke the capital chain, will cause the supplier, lessee and so on jointly implicated.

\section{Relative scarcity of professionals}

For the accurate evaluation of the equipment for leasing, it is necessary to understand both the accounting, financial and mechanical equipment. As a reasonable assessment directly affects the interests of financial leasing companies and tenants, the assessment of leasing equipment requires professional and prudent talent. However, with the rapid development of the financial leasing industry and the shortage of talents, the degree of talent specialization is difficult to meet the demand.

\section{E. The risk of management process is relatively large}

The risk of management process mainly includes interest rate and exchange rate. The fluctuation of interest rate can affect the rent burden, the financial leasing for large equipment often involves a longer period of time, with inflation and other factors change, prone to interest rate risk; Exchange rate risk is mainly manifested in the international leasing business, most of the financial leasing companies in the free trade zone are engaged in financial leasing business with foreign countries, exchange rate risk is more obvious. For example, a financial leasing company leases equipment to a lessee abroad and suffers financial losses as a result of the sudden depreciation of foreign currency at the time of paying the rent in foreign currency. If the foreign exchange transaction price when borrowing from a third country financial institution is low, but the foreign currency appreciates greatly when it is repaid in RMB, the financial leasing company will also face great exchange rate risk.

\section{OPTIMIZING ThE POLICY ENVIRONMENT STRATEGY SELECTION OF ThE FINANCIAL LEASING INDUSTRY IN FREE TRADE AREA}

\section{A. Expanding the financial leasing business and expanding the market for financial leasing}

In terms of education, though higher education has been supported by financial special funds, financing and renting fixed assets can alleviate the time lag caused by procedural examination and approval, thus forming a beneficial complement to the purpose of special funds [6]. In agriculture, reducing the income gap between urban and rural areas is the important goal of constructing modern agricultural technology system. At present, our country's agricultural base is weak, some advanced agricultural machinery equipment is expensive, and after the one-time purchase of agricultural machinery, such as some maize harvesting machinery, soil farming machinery and other machinery for a long period of time, but the maturity and cultivation period need specific machinery. Facing the problem of shortage of farmers 'funds, the introduction of financial leasing has its unique advantages. Many families pay the rent in rent instalments, and then share the rent according to the household, which not only improves the productivity but also brings the economic benefits of the financial leasing industry. In terms of housing, financial leasing companies can develop housing-related services, that is, financial leasing companies can purchase houses for housing buyers, who pay the rent on a regular basis and who retain the property after the expiration of the lease term. 


\section{3) Credit policy}

Commercial banks should strengthen their cooperation with other financial institutions, such as insurance and securities, in the financing channels of financial leasing companies. Bank loans to financial leasing companies to give certain preferential rate fluctuations, but to avoid the accumulation of systemic financial risk or to strictly examine loan applications. In addition, the city government can use the import and export bank to make long-term loans to the financial leasing industry in the free trade zone, and introduce commercial investors to actively fund the financial leasing industry.

A uniform regulatory standard should be put in place for the financial leasing industry as soon as possible, and the financial leasing business belonging to financial services should be submitted to the banking Regulatory Commission for examination and supervision, and other business should be submitted to the ministry of commerce for examination and control. As far as possible, the legislative content that regulates the legal relationship of financial leasing is centralized and included in a law. The norms of all aspects are unified in a single law, which is simple, uniform and improves the management efficiency.

\section{Strengthen the support of the Government and enhance its regulatory functions}

\section{1) Fiscal aspects}

For the tax effect of intertemporal financial leasing business, can be specified in the financial leasing contract, setting a regressive rental model (similar to the fixed assets of the accelerated depreciation), with the passage of time the amount is less and less, when the lease term begins because the lessor pay to the supplier price is larger, can set the highest rent the first period, after continuous regressive, the lessor need to pay value-added tax will face more and more heavy burden. This can not only reduce the default risk of the finance leasing company, but also solve the problem of the imbalance of the value added tax deduction. Taking into account the preferential tax policies such as "collect, return" or "collect, return" in the free trade area, other large equipment such as ships and medical care can be included in the scope of the import link as well as the aircraft without VAT or export link tax refund.

\section{2) The threshold of industry entry}

Appropriate to reduce the financial leasing industry access to registered capital requirements, to lease the company's own capital and debt ratio, leverage regulation, or government subsidies, for the newly established financial leasing companies subsidies according to their registered capital, may be required to be returned in the profits; The main contributors of the financial leasing companies should expand the scope and fully attract the unused funds of the society.

\section{Actively cultivate professional talents to maintain the stability of talent team}

Financial leasing involves a complex business scope, not only need rich theoretical basis but also need strong practical ability, so the professional quality of talent is very high, promote the combination of industry and research and the introduction of the training model. In addition, give professional personnel generous treatment, such as the return of personal income tax, including not only senior executives but also professional technical staff; Not only should the local share of salaries and salaries income tax be returned, but also should return the income tax of the income tax items such as the remuneration of services, concession transfer, while subsidizing the central share; Priority is given to meeting the needs of public services such as housing for senior managers and education for children.

\section{E. Strengthen the management of wind control and industry self-discipline}

We will strengthen the capacity of leasing agencies to assess their own risks, take timely measures against problems encountered, and strengthen supervision prior to and during events. In addition, when large equipment is leased or sold again, an authoritative evaluation of the quality and availability of the equipment is provided. For interest rate and exchange rate risks, there may be contractual agreement that significant changes in interest rate and exchange rate should be accompanied by rent adjustments. Facing the credit risk of the leasing enterprise, we should make full use of the credit management system of the commercial bank and provide the credit information inquiry service of the leasing enterprise for the relevant units such as the financial leasing company [6].

\section{CONCLUSION}

In the background of "The Belt and Road" initiative and the global trade liberalization, on the basis of the advanced experience of developed countries in financial leasing industry, the Free Trade Area should continue to develop with its own features of the financial leasing mode, expand the broader business types. The Free Trade Area can use the public policy of Support finance and science and technology innovation, by actively introduce foreign capital and innovate business types to consolidate and develop the important position of financial leasing industry in the free trade area. 


\section{ACKNOWLEDGMENT}

Wei Li, Male, (1980- ), Nation: Han

Native: Harbin, Heilongjiang Province, China

$\mathrm{PhD}$ in Economics

Associate Professor, Department of Finance and Public Management, School of Economics, Tianjin University of Finance and Economics

The main research direction: financial risk theory and policy

Email: liwei1101@126.com

Congcong Bian Female (1992- ), Nation: Han, Native: Dezhou, Shandong Province, China

Graduate students in Finance, Students of the Department of Finance and public administration of Tianjin University of Finance and Economics.

Email: 13820906512@163.com (sponsors).

\section{REFERENCES}

[1] Zhongqin Jiang. Financial Leasing in China and Solutions [M] Beijing: Contemporary China Press. 2008.

[2] Sudier. Full Guide to International Leasing Limingzhi et al.)[M] .Beijing Beijing University Press, 2007:87-107.

[3] Xiong Lin. China's Free Trade Area Construction and International Experience [M]. Guangzhou: Zhongshan University Press, 2016.

[4] Zhijian Zhang. Problems and Countermeasures of Financial Leasing Development in China [J] .Shandong Social Sciences. 2015(3): 123-126.

[5] Dongqiang Wang, ShuqinTian. Risk Analysis and Prevention System Reconstruction of Financial Leasing [J]. SME finance. 2008(03): 13-16.

[6] Shin Seung-Myo, An Empirical Study on Tax and Nontax Factories Accounting First Decisions on Lease Use and Lease Type Choice, Korean Journal of Taxation Research, Vol. 26 No. 1, 2009. 